DOI:

УДК 656.135 .8

B.P. Sereda, Head of the Department of Cars and Automobile Economy, Doctor of Tech. Sci., Prof.

D.Y. Mukovska, postgraduate

Dniprovsk State Technical University, Kamianske

\title{
RESEARCH PROCESS OF TECHNOLOGICAL WASTE RECYCLING IN THE CONDITIONS OF THE METALLURGICAL ENTERPRISE CAREER
}

Analyzes the volume, structure, and recycling of major technological wastes from the metallurgical enterprise. The expediency of their use in own production is shown. The chemical composition of the main types process wastes is given in percentage. The degree of the total amount recycling for major technological waste is determined.

Keywords: technological waste; blast furnace slag; open-hearth slag; recycling; blastfurnace; open-hearth shop; slag-processing shop.

Проаналізовані об'єм, структура, та рециклінг основних технологічних відходів металургійного підприємства. Наведені основні види та обсяги основних технологічних відходів, які поступають до переробки. Показана доциільність їх використання у власному виробнищтві. Наведений у відсотковому відношенні хімічний склад основних видів технологічних відходів. Визначено ступінь рециклінгу від загального об'єму виникнення основних технологічних відходів.

Ключові слова: технологічні відходи; доменний шлак; мартенівський илак; рециклінг; доменний цех; мартенівський цех; цех шлакопереробки.

\section{Problem's Formulation}

As a result of intensive development of mining and metallurgical industry, a considerable amount of technogenic deposits is formed, on which technogenic waste is largely accumulated. In recent years, due to the formation and accumulation of a large amount of industrial waste and the need to solve environmental problems, the importance of integrated waste management has increased. The technological processes associated with the processing of natural raw materials into industrial products are accompanied by the formation of a significant amount of waste. The metallurgical industry occupies an important place in the economy of the country, being the basic industry, characterized by significant volumes of production and production costs of finished goods. Considering the problem of resource conservation, for many mining and metallurgical enterprises, man-made deposits may become the only sources of metallurgical raw materials. A large amount of technological waste from mining and metallurgical enterprises is concentrated in the waste heaps. Technology dumps are deposits of various minerals that after processing are involved in reuse in production. Processing of process waste allows to obtain relatively cheap raw materials on the one hand and to reduce the impact of environmental pollution on the other [1-3].

One of the types of process waste is metallurgical slag. Metallurgical slag accounts for a large part of the waste of metallurgical production, which is a man-made mixture of metal and oxide components, each of which is a valuable raw material [4].

The processing and disposal of slag makes it possible to solve one of the most important environmental problems - the clearing of territories from large-scale waste, which is the slag of metalurgical production. Slag dumps serve as sources of dust formation, pollute groundwater and surface sources with heavy metals, occupying considerable land areas. The factories are interested in the organization of the process of slag processing not only for environmental but also for economic reasons. According to studies, the content of metal in the slag reaches up to $15 \%$. Extraction of metal components from the slag and their use for the production of steels and alloys can significantly increase the economic performance of metallurgical production.

\section{Analysis of recent research and publications}

With the current rate of increase in iron production and metal processing, the problem of resolving the return of metallurgical waste and machining to production is an acute problem. In the 
process of steel production, metal losses are observed at every stage of the technological cycle, from iron ore extraction to steel rolling. This is due to the use of outdated equipment of metallurgical enterprises, low payment for emissions, discharges and disposal of waste, imperfect legislation in the field of subsoil use and environmental protection [5].

Slag is a technological waste that is generated at high temperatures due to the physical chemical interaction of the components of the source solid materials and the gas environment. They occupy large areas of land for which the plant pays a fairly high fee [6].

Ways of applying slag are quite diverse. Metallurgical slag plays a major role in the generation of waste, but their main application is not related to metallurgical processing. Much of the slag is processed in the liquid state to produce granular slag, for the production of cement, some used in steel smelting. Steelmaking is used both in metallurgy and in the production of fertilizers, abrasives, and in construction. Fractionated and ordinary slag rubble is used in road and industrial construction, which allows to reduce the volume of natural stone materials and to reduce the scale of environmental disturbances caused by their development. Also, considerable amounts of slag are used in the erection of dams and seepage tanks and other objects of industrial hydraulic engineering [7].

Recycling and processing of industrial waste is one of the main problems that modern metallurgical enterprises need to solve. Metallurgical processes take place at a considerable expense of various material and raw material resources, which make up to $7 \mathrm{t} / \mathrm{t}$ from the extraction of ore to the receipt of finished rolled metal. The specific consumption of only the main types of material resources in ferrous metallurgy is, $t / t$ of the product: in sinter production $1,27-1,32$, in the production of iron $1,70-2,00$, in the production of steel $1,08-1,15$, rolling - 1,12-1,50. At this level of production, thousands of different types of industrial waste are generated. Thus, the specific output of sludge and dust in sintering, blast furnace, steelmaking and rolling shops are respectively $0,07-0,16 ; 0,06-0,22$, $0,01-0,03$ and $0,03-0,07 \mathrm{t} / \mathrm{t}$ of product [8].

Metallurgical enterprises of Ukraine have accumulated 240 million tones of slag, 128 million tones of which are steelmaking. The number of accumulated slag in Ukraine leads the Yenakiyevo Metallurgical Plant, ArcelorMittal Kryvyi Rih and Zaporizhstal. Typically, blast furnace slag is separated from the smelter. The mass fraction of iron in them is $5 \%$ in the form of queens. The most interesting for attracting further processing are steelmaking slag which contains more metal $-10-15 \%$. The specific yield of steel-slag slag is, on average, $160-170 \mathrm{~kg} / \mathrm{t}$ of steel [9].

For the integrated use of slag, it is efficient to remove residual iron from them and to attract for further use. To solve this problem, it is necessary to select a method and create the conditions for the effective removal of iron from them (iron ore concentrate) in a separate product and obtain material for further use.

Goal setting

Analyze the volume, structure, and recycling of major technology. List the main types and volumes of major process wastes that are being recycled. Show the feasibility of using them in your own production. Give the chemical composition of the main types of technological waste. Determine the degree of recycling of the total amount of major technological waste generated

\section{Presenting main material}

Given the scarcity of iron ore for many metallurgical enterprises, namely, the south of Ukraine, the use in the technological cycle of waste of own production in our time is to a large extent or not the main and appropriate reserve for reducing production costs and improving economic performance of metallurgical production. At the metallurgical production of the plant of PJSC "Zaporizhstal", metallurgical slag, namely blast furnace and open-hearth waste, is the major part of the ferrous waste generated in the production cycle. Metallurgical slag occupies vast areas and interacts with the environment, causing enormous damage to the environment. Process wastes that are not utilized in the production cycle or stored temporarily, pending processing, are placed in the slag processing plant. The volumes of occurrence of major process wastes are presented in Tabl. 1. 
Table 1. Volumes of occurrence of the main technological wastes of metallurgical plant "Zaporizhstal" for 2016-2018

\begin{tabular}{|l|c|c|c|}
\hline \multirow{2}{*}{ Type of waste } & \multicolumn{3}{|c|}{ Volumes of occurrence of the main technological wastes, thousand tons } \\
\cline { 2 - 4 } & $\mathbf{2 0 1 6}$ & $\mathbf{2 0 1 7}$ & $\mathbf{2 0 1 8}$ \\
\hline Blast slag & 1484,925 & 1491,953 & 1757,416 \\
\hline Martenovsky slag & 480,874 & 479,327 & 489,158 \\
\hline
\end{tabular}

Given the scale of occurrence, special attention is paid to the issue of slag processing at the mill. The production facilities located in the slag processing plant make it possible to prepare and recycle slags of current production and previously accumulated in waste heaps. The volumes of recycling of the main process wastes are presented in Tabl. 2. In the territory of the slag processing plant the transportation of slag is carried out by dump trucks. Today, dump trucks are widespread in the mining industry. Career dump trucks are one of the main means of transportation of metallurgical slag and products of their processing $[10,11]$.

Table 2. Recycling volumes of the main technological wastes of metallurgical plant «Zaporizhstal" for 2016-2018

\begin{tabular}{|l|c|c|c|}
\hline \multirow{2}{*}{$\begin{array}{c}\text { Type of waste at the } \\
\text { point of origin in the } \\
\text { production cycle }\end{array}$} & \multicolumn{3}{|c|}{ Recycling volumes of major process wastes, thousand tons } \\
\cline { 2 - 4 } & $\mathbf{2 0 1 6}$ & $\mathbf{2 0 1 7}$ & $\mathbf{2 0 1 8}$ \\
\hline blast furnace production & 751,948 & 931,290 & 845,584 \\
\hline open-hearth production & 270,539 & 283,971 & 298,574 \\
\hline
\end{tabular}

The uses of the slag processing products depend on the physical and chemical properties of the recyclable materials. Blast slags in chemical composition are almost indistinguishable from natural silicates. They are well granular and therefore can be used in the construction industry. The Marten slag is different from blast furnace slag, both in chemical properties and in application. The products of processing open-hearth slag are used in our own production. [12].

The approximate chemical composition of the major process wastes generated in the production cycle is shown in Tabl. 3.

Table 3. Chemical composition of the main process wastes formed in the production cycle of metallurgical plant "Zaporizhstal"

\begin{tabular}{|l|c|c|c|c|c|c|c|c|c|}
\hline \multirow{2}{*}{$\begin{array}{l}\text { Type of } \\
\text { waste }\end{array}$} & \multicolumn{7}{|c|}{ Chemical composition of blast furnace slag,\% } \\
\cline { 2 - 9 } & $\mathrm{SiO}_{2}$ & $\mathrm{CaO}$ & $\mathrm{MnO}$ & $\mathrm{FeO}$ & $\mathrm{AL}_{2} \mathrm{O}_{3}$ & $\mathrm{MgO}$ & $\mathrm{S}$ & $\frac{\mathrm{CaO}}{\mathrm{SiO} \mathrm{O}_{2}}$ & $\begin{array}{c}(\mathrm{CaO}+\mathrm{MgO}) \\
\mathrm{SiO}\end{array}$ \\
\hline Blast slag & 40,105 & 47,106 & $\begin{array}{c}0,12 \\
2\end{array}$ & $\begin{array}{c}0,18 \\
4\end{array}$ & 8,130 & 3,824 & 0,969 & 1,176 & 1,271 \\
\hline $\begin{array}{l}\text { Type of } \\
\text { waste }\end{array}$ & \multicolumn{7}{|c|}{ The chemical composition of the open-hearth slag,\% } \\
\cline { 2 - 9 } & $\mathrm{SiO}_{2}$ & \multicolumn{2}{|c|}{$\mathrm{CaO}$} & $\mathrm{MnO}$ & $\mathrm{FeO}$ & $\mathrm{AL}_{2} \mathrm{O}_{3}, \mathrm{Cr}_{2} \mathrm{O}_{3}$ \\
\hline $\begin{array}{l}\text { open-hearth } \\
\text { slag }\end{array}$ & 24,24 & \multicolumn{2}{|c|}{51,34} & 13,46 & 9,03 & 1.93 \\
\hline
\end{tabular}




\section{Conclusions}

Technological waste of production is undesirable but also inevitable products of technological activity. Production wastes are a sign of the imperfection of technology and organization of production and consumption. Analyzing the above, we can conclude that the use of technological waste solves a complex of issues to reduce man-made load on nearby areas, reduces the need for primary raw materials, reduces environmental pollution, reduces the land area of technological waste accumulation.

As a result of the analysis of the production process, the degree of recycling of the main technological wastes was determined, which is $53 \%$ for blast furnace slag, and for $58 \%$ for open-hearth. Therefore, the recycling of technological waste is appropriate not only from an environmental but also from an economic point of view.

Thus, in the conditions of PJSC "Zaporizhstal" the implementation of measures for recycling of technological waste of the main production allowed to partially solve the problem of shortage of iron ore raw materials and improve the environmental situation in the region.

\section{References}

[1] Sereda B. P., Mukovs'ka D. Ya. (2018). Dosli'dzhennya efektivnosti' roboty samoskidiv BelAZ $\mathrm{v}$ umovakh kar'yeru metalurgi'jnogo pi dpriyemstva [Investigation of the efficiency of BelAZ dump trucks in the career of metallurgical enterprise] Perspektivi tekhnologi'yi ta priladi Technology perspectives and devices, (№ 13), 125-131 [in Ukrainian].

[2] Fedyushko M. P. (2012). Stan promyslovykh vi`dkhodi'v mi`sta Mari`upol` ta yikh utili’zaczi'ya [The state of industrial waste in the city of Mariupol and their disposal] VI'snik Ahrarnoi nauky Prychornomoria'ya - Bulletin of Agrarian Science of the Black Sea Coast, (№ 2), 187-195 [in Ukrainian].

[3] Plotni kov V. V., Yarosh T. P., Marasanova O. V. (2012) Perspektivi utili zaczi yi promyslovykh vi'dkhodi'v u metalurgi jnomu virobnicztvi` [Prospects for utilization of industrial waste in metallurgical production] Vi`snik Krivori`z'kogo naczi’onal’nogo uni`versitetu - Bulletin of Kryvyi Rih National University, (№ 3), 215-219 [in Ukrainian].

[4] Kuatov D. B. (2016) Pererabotka shlaka v chernoj metallurgii putem droblenyia i yzvlechenyia dopolnitel'nogo sy' $r$ 'ya [Processing of slag in ferrous metallurgy by crushing and extracting prefiller raw materials] Nauka i tekhnyka Kazakhstana - Science and technology of Kazakhstan, (№3), 88-90 [in Kazakhstan].

[5] Rud V. D., Saviuk V. D., Samchuk L. M. (2015) Analiz kilkosti’ utvorenykh vidkhodiv mashynobuduvannia ta metalurgi 'i na teritori'yi Ukrainy [Analysis of the amount of generated waste of mechanical engineering and metallurgy on the territory of Ukraine] Visnyk TNTU - Bulletin of TNTU, (№ 3), 130-136 [in Ukrainian].

[6] Avramenko S. Kh., Volokh Yu. V. (2010) Ekologi 'chni` problemi vi`d nakopichennya tverdikh promyslovykh vidkhodiv ta shlyahi vykorystannia metalurgi jnikh shlakiv [Environmental problems from the accumulation of solid industrial waste and ways of using metallurgical slag] Zbirnyk naukovykh parch` Naczi'onal'nogo gi'rnichogo uni 'versitetu - Proceedings of the National Mining University, (№35), 200-206 [in Ukrainian].

[7] Yegorov K. V. (2010) Analiz vidkhodiv metalurgi jnogo virobnicztvi [Analysis of metallurgical waste] Speczi'al`na metalurgi'ya: vchora, sohodni', zavtra - Special Metallurgy: yesterday, today, tomorrow, 193-196 [in Ukrainian].

[8] Kotov Yu. T., Razkevich F. S., Goncharova K. V. (2012) Analiz’z utvorennia vi’dkhodi 'v metalurgi'jnogo virobnicztvi i rozrobka metodiv'v yikh povtornoho vykorystannia na PAT "Arselormmital Kryvyi Rig'g" [Analysis of waste generation of metallurgical production and development of methods for their re-use at PJSC "Arselormmital Kryvyi Rih"] Gi'rnichij vi'snik - Mining Bulletin, (№ 95), 232-236 [in Ukrainian].

[9] Ni kolayenko K. V., Samoilenko N. A. (2016) Kompleksne vykorystannia metalurgi’jnikh shlakiv [Integrated use of metallurgical slag] Zbahachennia korysnykh kopalyn - Enrichment of minerals, (Vup. 64, №105), 1-5 [in Ukrainian]. 
[10] Sereda B. P., Mukovska D. Ya. (2018) Optimi`zaczi`ya roboty metalurgi`jnogo pi`dpriyemstva shlyakhom analizu ekspluataczi jnikh pokaznykiv kar'yernikh samoskidiv [Optimization of the metallurgical enterprise by analyzing the performance of quarry dump trucks] / B. P. Matematychne modeliuvannia - Mathematical modeling, (№ 2), 163-169 [in Ukrainian].

[11] Sereda B. P., Mukovska D. Ya. (2018) Zakhody pi'dvishhennya samoskidiv v umovakh kar'yeru metalurgi jnogo pi'dpriyemstva [Measures to increase dump trucks in the quarry of a metallurgical enterprise] Vi`snik NTU "KhPI " - Bulletin of NTU "KPI", (№ 23), C. 62-66 [in Ukrainian].

[12] Nazyuta L. Yu., Smotrov A. V., Gubanova A. V. (2011) Struktura obrazovaniya i reczikling tehnologicheskih otkhodov na metallurgicheskikh predpryiatyiakh polnoho czicla [The structure of formation and recycling of technological waste at full-cycle metallurgical enterprises]/ Energotekhnologii i resursosberezhenye - Energy technologies and resource saving, (№ 4), 44-54 [in Ukrainian].

\section{РЕЦИКЛІНГ ТЕХНОЛОГІЧНИХ ВІДХОДІВ В УМОВАХ КАР'ЄРУ МЕТАЛУРГІЙНОГО ПІДПРИЕМСТВА \\ Середа Б.П., Муковська Д.Я.}

\section{Реферат}

У даній статті проаналізовані об'єм, структура, та рециклінг основних технологічних відходів металургійного підприємства ПАТ «Запоріжсталь» 2016-2018 рр. Наведені основні види та обсяги основних технологічних відходів, які поступають до переробки . Показана доцільність їх використання у власному виробництві. Наведений у відсотковому відношенні хімічний склад основних видів технологічних відходів. Визначено ступінь рециклінгу від загального об'єму виникнення основних технологічних відходів.

В результаті аналізу виробничого процесу було визначено ступінь рециклінгу основних технологічних відходів, який складає для доменного шлаку - 53 \%, для мартенівського 58 \%. Тому рециклінг технологічних відходів $є$ доцільним не тільки з екологічної, а і з економічної точки зору.

Таким чином в умовах ПАТ «Запоріжсталь» застосування заходів по рециклінгу технологічних відходів основного виробництва дозволило частково розв'язати проблему дефіциту залізорудної сировини та покращити екологічну ситуацію у регіоні.

\section{Література}

1. Середа Б. П., Муковська Д. Я. Дослідження ефективності роботи самоскидів БелАЗ в умовах кар'єру металургійного підприємства. Перспективи технології та прилади. 2018. №13. С. $125-131$.

2. Федюшко М. П. Стан промислових відходів міста Маріуполь та їх утилізація. Вісник Аграрної науки Причорномор'я. 2015. №2. С. 187-195.

3. Плотніков В. В., Ярош Т. П., Марасанова О. В. Перспективи утилізації промислових відходів у металургійному виробництві. Вісник Криворізького наиіонального університету. Кривий Ріг. 2012. №3. С. 215-219.

4. Куатов Д. Б. Переработка шлака в черной металлургии путем дробления и извлечения дополнительного сырья. Наука и техника Казахстана. 2016. №3. С. 88-90.

5. Аналіз кількості утворених відходів машинобудування та металургії на території України. В. Д. Рудь, І. В. Савюк, Л. М. Самчук, Ю. С. Повстяна. Вісник ТНТУ. 2015. №3. С. 130-136.

6. Авраменко С. Х., Волох Ю. В. Екологічні проблеми від накопичення твердих промислових відходів та шляхи використання металургійних шлаків. Збірник наукових пращь Національного гірничого університету. 2010. №35. С. 200-206. 
7. Сгоров К. В. Аналіз відходів металургійного виробництва. Спеціальна металургія: вчора, сьогодні, завтра. 2010. С. 193-196.

8. Котов Ю. Т., Разкевич Ф. С., Гончарова К. В. Аналіз утворення відходів металургійного виробництва і розробка методів їх повторного використання на ПАТ "Арселорммітал Кривий Ріг". Гірничий вісник. 2012. №95. С. 232-236.

9. Ніколаєнко К. В., Самойленко Н. А. Комплексне використання металургійних шлаків. Збагачення корисних копалин. 2016. Вип. 64(105). С. 5.

10.Середа Б. П., Муковська Д. Я. Оптимізація роботи металургійного підприємства шляхом аналізу експлуатаційних показників кар'єрних самоскидів. Математичне моделювання. 2018. №2. С. 163-169.

11. Середа Б. П., Муковська Д. Я. Заходи підвищення самоскидів в умовах кар'єру металургійного підприємства. Вісник НТУ "ХПІ". Харків. 2018. №23. С. 62-66.

12. Структура образования и рециклинг технологических отходов на металлургических предприятиях полного цикла. Л. Ю. Назюта, А. В. Смотров, А. В. Губанова, Г. В. Корнев. Енерготехнологии и ресурсосбережение. 2011. №4. С. 44-54. 